\title{
Should We Stop Blaming Saturated Fats for Causing Coronary Heart Disease? A Systematic Review of Prospective Cohort Studies
}

\author{
Sulaiman Salim Al Mashrafi ${ }^{1}$, Hilal Salim Al Shamsi ${ }^{2}$ \& Abdullah Ghthaith Almutairi ${ }^{3}$ \\ ${ }^{1}$ Directorate General of Planning and Studies, Department of Health Information and Statistics, Muscat, Ministry \\ of Health, Oman \\ ${ }^{2}$ Directorate General of Planning and Studies, Directorate General of Health Services, Al-Buraimi Governorate, \\ Ministry of Health, Oman \\ ${ }^{3}$ Quality Department, Prinice Nasser Hospital, Al-Ghat Province, Ministry of Health, Saudi Arabia \\ Correspondence: Hilal Salim Al Shamsi, Directorate General of Planning and studies, Directorate General of \\ Health Services, Al-Buraimi Governorate, Ministry of Health, Oman.
}

Received: March 24, 2018 Accepted: April 8, 2018 Online Published: April 27, 2018

doi:10.5539/gjhs.v10n6p62 URL: https://doi.org/10.5539/gjhs.v10n6p62

\begin{abstract}
Background: Coronary heart disease (CHD) is a leading cause of death worldwide. Saturated fats were known as a risk factor for CHD and dietary guidelines restrict the daily consumption of SFs. However, the association between SFs and higher risk of CHD is not clear. This systematic review includes 14 high-quality prospective cohort studies which reported the association between CHD and SFs.
\end{abstract}

Objective: This systematic review aims to examine the association between SFs intake and higher risk of CHD among prospective cohort studies.

Design: A systematic review was conducted for published literaure in Scopus and ProQuest during the period 2000 to 2017. Studies included if they have a prospective cohort design with follow-up more than 4 years, published in English, and provide information about the association of interest. Data were extracted and summarised into three tables.

Results: A total number of 14 prospective cohort studies were included in this review in which all from developed countries and half of them were from the USA. The total number of participants ranging from 501 to 344,696 in follow-up period from 4.8 to 30 years where 26,322 events of CHD and 629 CHD deaths were reported. The highest positive association HR (95\%CI) was 5.17 (1.64-16.36) for CHD mortality and $1.36(0.98-1.88)$ for CHD incidence. In contrast, the highest inverse association was found 0.73 (0.53-1.01) for CHD mortality and 0.62 (0.35-1.11) for CHD incidence.

Conclusion: This systematic review suggests that SFs intake was not associated with higher incidence or mortality of CHD.

Keywords: fat intake, fat consumption, Ischemic heart disease, coronary artery disease, cardiovascular disease, prospective cohort, observational study

$\begin{array}{ll}\text { Abbreviations } & \\ \text { SFs } & \text { Saturated fats } \\ \text { MUFAS } & \text { Monosaturated fats } \\ \text { PUFAs } & \text { Polysaturated fats } \\ \text { Carbs } & \text { Carbohydrates } \\ \text { BMI } & \text { BODY MASS INDEX } \\ \text { CAD } & \text { CORONARY ARTERIAL DISEASE } \\ \text { CI } & \text { CONFIDENCE INTERVAL }\end{array}$




$\begin{array}{ll}\text { CVDs } & \text { CARDIOVASCULAR DISEASEs } \\ \text { CHD } & \text { Coronary Heart Disease } \\ \text { RR } & \text { RELATIVE RISK } \\ \text { HR } & \text { HAZARD RATIO } \\ \text { NHS } & \text { Nurses' Health Study } \\ \text { HPFS } & \text { Health Professionals Follow-up Study } \\ \text { FV } & \text { Fruits and Vegetables }\end{array}$

\section{Introduction}

None-communicable diseases (NCDs) are a silent pandemic and spreading rapidly across the world (Lins, Jones, \& Nilson, 2010). The changes in lifestyles and behaviours of people are major contributions to chronic diseases. These changes were accompanied by the demographic, epidemiological and the nutritional transition (Zimmet \& Alberti, 2006). Therefore, ageing population and risk factors such as obesity, high cholesterol, physical inactivity and bad dietary habits are a public health concern for governments worldwide (Christensen, Doblhammer, Rau, \& Vaupel, 2009). Thus, governments have developed their national guidelines for diets and other risk factors to curb the burden of NCDs.

Dietary recommendations and guidelines should be based on evidence and modified to be appropriate for each country individually (Hoenselaar, 2012). Therefore, it is important that findings from scientific literature be consistent to strongly support the recommended levels based on clear evidence (Hoenselaar, 2012). One of the most important dietary guidelines is the intake of daily level of energy particularly the saturated fats. Dietary guidelines recommend restricting the daily intake of SFs because it is believed that SFs are strongly associated with NCDs especially CVDs (de Oliveira Otto, et al., 2012; Perk et al., 2013). However, the relation between SFs intake and the CVDs has been controversial and recent evidence doesn't support this paradigm (Baum et al., 2012; Siri-Tarino, Sun, Hu, \& Krauss, 2010).

CVDs are the leading cause of death worldwide where they were responsible for about 17.7 million deaths in 2015 (WHO, 2017). However, Coronary Heart Disease (CHD) is the most prevalent type of CVDs. Out of the 17.7 million deaths, there were 7.4 million deaths (42\%) due to CHD (WHO, 2017). The World Health Organisation defines CHD as "disease of the blood vessels supplying the heart muscle" (WHO, 2017). CHD is also known as Coronary Artery Disease (CAD) or Ischemic Heart Disease (WebMD, 2005; Wikipedia tfe, 2017). Thus, addressing the risk behaviours related to CVDs in general and particularly to CHD is paramount. These behaviours include the daily level of SFs intake to stop the rapid spread of the incidence of CHD. Dietary guidelines recommend consuming (7\%-10\%) of SFs as a total of energy intake every day (Parodi, 2015).

In recent years, there are different debates and arguments about the association between the risk of CHD and SFs intake which may change the bad picture of SFs. For instance, two recent meta-analyses found that there is no association was found between the higher risk of CHD and the higher intake of SFs (Siri-Tarinoet al., 2010; Chowdhury et al., 2014). This conclusion was supported by a third meta-analysis published in 2015 (De Souza et al., 2015). In contrast, dietary guidelines continue to ask people to limit the intake of SFs. The conflict in findings leads to the confusion among consumers as well as among advice givers such as dieticians. Therefore, research around this area should continue to clear this confusion and eliminate the uncertainties about the relation of SFs and CHD.

Thus, this paper aims to systemically review the association between CHD and SFs intake from recent prospective cohort studies. High quality and peer-reviewed cohort studies will be included in which the association of SFs and CHD was reported. The focus on CHD is due to the fact that CHD is a leading cause of death worldwide and the most prevalent type of CVDs.

\section{Subjects and Methods}

\subsection{Data Sources and Searches}

A systematic review was performed to obtain prospective cohort studies about the association between CHD and SFs intake. Databases used during the search method including Scopus and ProQuest. Different keywords and terms were used to get the related articles such as "the association", "the relation", "saturated fats", "total fats", "fat intake", "fat consumption", "coronary heart disease", "ischemic heart disease", "coronary artery disease", "cardiovascular disease", "prospective cohort", "observational study". These keywords were used to find articles with the same expressions in the title or the abstract of the article. The search strategy was restricted to English 
language articles published during the period 2000 to 2017 to come up with the most recent literature around the topic.

\subsection{Inclusion and Exclusion Criteria}

This review includes observational prospective cohort studies which report the association between SFs intake and CHD published in English from the year 2000 to 2017. The end points included in this review either CHD mortality or CHD incidence. However, studies with small sample size $(n<500)$ and short follow-up duration $(<4$ years) were excluded. In addition, articles which were not peer reviewed were excluded. Furthermore, the exclusion was applied to articles with other CVDs other than CHD.

\subsection{Data Extraction}

The extracted data were summarised in two separate table. The first table contains the general characteristics of each study included in this review. Particularly, the first table includes information about the year of the study, country, $\%$ of males, age range at baseline in years, follow-up periods in years, outcome (incidence or mortality) and the dietary measurement tool.

The second table focuses on the findings on the association between CHD and SFs intake in each study. In addition, it lists the adjusted variable and includes information about the level of SFs intake among participants. Information about the total events (CHD deaths or incidence) were also summarised in the second table for each study.

\section{Results}

Figure 1 shows the process of selecting the eligible studies included in this review. At the first stage, there were 2,674 retrieved from Scopus and ProQuest. After removing the duplicated articles and those published before the year 2000, the number of the remaining articles was 621. Furthermore, not peer reviewed articles (264) and not prospective cohort studies (225) were excluded. The total number of articles included in this review is 14 after excluding those studies with sample size less than 500 and the follow-up duration is less than 4 years. 
Total records from ProQuest $=1215$

Total records from Scopus $=1459$

Total records included after duplicates removed $=1141$

Articles published before $2000=520$

Publications after 2000 included $=621$

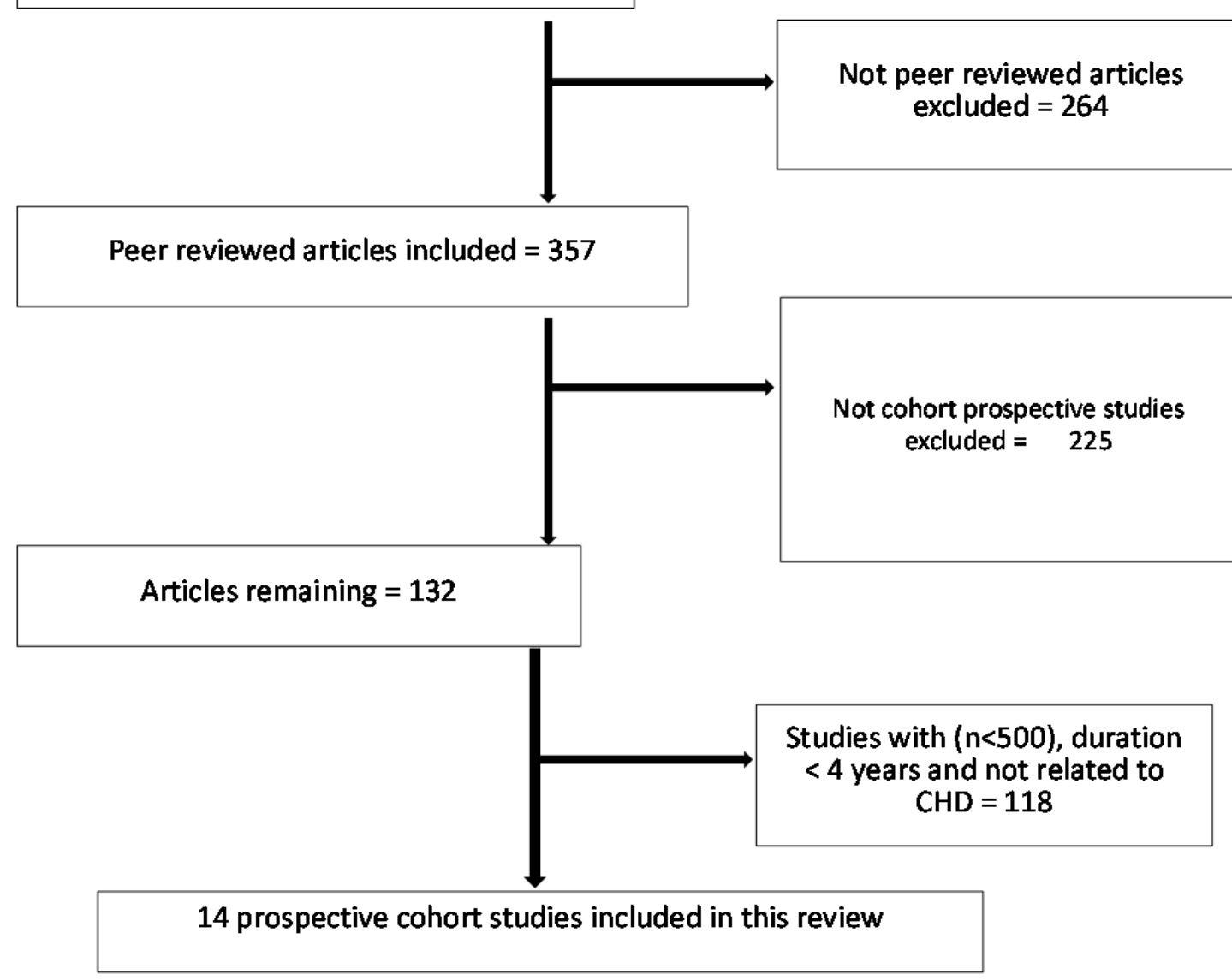

Figure 1 . The process of selecting the 14 articles which are included in this study 
Table 1. General characteristics of the included studies

\begin{tabular}{|c|c|c|c|c|c|c|c|}
\hline 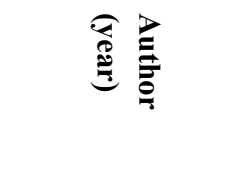 & $\stackrel{\Omega}{ٍ}$ & $=$ & 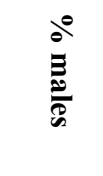 & 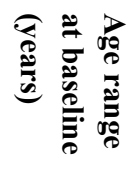 & 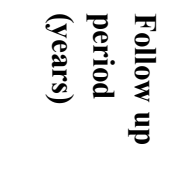 & 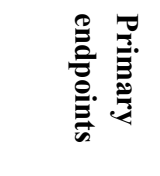 & 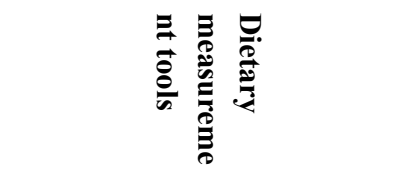 \\
\hline $\begin{array}{l}\text { Jakobsen et al, } \\
2004\end{array}$ & Denmark & 3,686 & $49.8 \%$ & $30-71$ & 16 & CHD cases & $\begin{array}{l}\text { 7-day weighed food record or } \\
\text { a dietary history interview. }\end{array}$ \\
\hline Oh et al, 2005 & USA & 78,778 & $0 \%$ & $30-55$ & 20 & CHD cases & Food frequency questionnaire. \\
\hline Tucker et al, 2005 & USA & 501 & $100 \%$ & $34-80$ & 18 & $\begin{array}{l}\text { CHD } \\
\text { mortality }\end{array}$ & $\begin{array}{l}\text { Fruits \& Vegetables: dietary } \\
\text { records }\end{array}$ \\
\hline Xu et al, 2006 & USA & 2,938 & $35.7 \%$ & $47-79$ & 7 & $\begin{array}{l}\text { CHD } \\
\text { mortality }\end{array}$ & 24 hours dietary recall. \\
\hline $\begin{array}{l}\text { Leosdottir et al, } \\
2007\end{array}$ & Sweden & 28,098 & $39 \%$ & $45-73$ & 8 & CHD cases & 7-day menu diary \\
\hline $\begin{array}{l}\text { Jakobsen et al, } \\
2009\end{array}$ & $\begin{array}{l}\text { USA } \\
\text { Europe }\end{array}$ & 344,696 & $29 \%$ & $37-76$ & 6.5 & CHD cases & $\begin{array}{l}\text { Dietary history interview } \\
\text { Food Frequency questionnaire }\end{array}$ \\
\hline $\begin{array}{l}\text { Yamagishi et al, } \\
2010\end{array}$ & Japan & 58,453 & 39.4 & $40-79$ & 14.1 & $\begin{array}{l}\text { CHD } \\
\text { mortality }\end{array}$ & Food-frequency questionnaire. \\
\hline $\begin{array}{l}\text { Oliveria Otto et al, } \\
2012\end{array}$ & USA & 5,209 & $47 \%$ & $45-84$ & 10 & CHD cases & Food-frequency questionnaire. \\
\hline $\begin{array}{l}\text { Virtanen et al, } \\
2014\end{array}$ & Finland & 1,981 & $100 \%$ & $42-60$ & 21.4 & CHD cases & 4-day food recording \\
\hline Li et al, 2015 & USA & 127,536 & $34 \%$ & $30-75$ & $\begin{array}{l}\text { NHS: } 30 \\
\text { HPFS: } 24\end{array}$ & CHD cases & Food frequency questionnaire. \\
\hline $\begin{array}{l}\text { Puaschitz et al, } \\
2015\end{array}$ & Norway & 2,412 & $81 \%$ & $27-86$ & 4.8 & CHD cases & Food-frequency questionnaire \\
\hline $\begin{array}{l}\text { Praagman et al, } \\
2016\end{array}$ & Netherlands & 35,597 & $25 \%$ & $20-70$ & 12 & CHD cases & Food frequency questionnaire \\
\hline $\begin{array}{l}\text { Praagman et al, } \\
2016\end{array}$ & Netherlands & 4,722 & $38 \%$ & $\begin{array}{l}\geq 55 \\
\text { years }\end{array}$ & 16 & CHD cases & Food frequency questionnaire. \\
\hline Zong et al, 2016 & USA & 115,782 & $37 \%$ & $30-75$ & $\begin{array}{l}\text { Male: } 21.2 \\
\text { Female: } 25.8\end{array}$ & CHD cases & Food frequency questionnaire \\
\hline
\end{tabular}


Table 2. Important findings from the 14 studies

\begin{tabular}{|c|c|c|c|c|c|c|}
\hline $\begin{array}{l}\text { Author } \\
\text { (year) }\end{array}$ & $\begin{array}{lr}\quad(\% \mathrm{SF} & \text { of } \\
\text { total } & \text { fat } \\
\text { intake) } & \end{array}$ & $\begin{array}{l}\text { Number } \\
\text { of events }\end{array}$ & Findings & & Control variables & Comments \\
\hline $\begin{array}{l}\text { Jakobsen } \\
\text { et al, } 2004\end{array}$ & $\begin{array}{l}\text { Male: } 19.7 \% \\
\text { Female: } \\
19.5 \%\end{array}$ & $\begin{array}{l}\mathrm{CHD} \\
\text { cases } \\
326\end{array}=$ & $\begin{array}{l}\begin{array}{l}\text { Overall } \\
(\text { women) }\end{array}= \\
95 \% \\
(0.98-1.88) \\
\text { Overall } \\
(\text { men) }= \\
95 \% \\
(0.78-1.37) .\end{array}$ & $\begin{array}{r}\text { HR } \\
1.36, \\
\text { CI } \\
\text { HR } \\
1.03, \\
\text { CI }\end{array}$ & $\begin{array}{l}\text { Family history of myocardial } \\
\text { infarction, education, smoking, } \\
\text { leisure PA, alcohol, dietary fibre, } \\
\text { dietary cholesterol, cohort } \\
\text { identification, total fat intake and } \\
\text { the \% of fat intake from the total } \\
\text { energy intake. }\end{array}$ & $\begin{array}{l}\text {-The risk of CHD } \\
\text { among women with } 5 \% \\
\text { higher intake of SFs is } \\
\text { greater by } 36 \% \text { and no } \\
\text { overall association was } \\
\text { found for men. }\end{array}$ \\
\hline
\end{tabular}

\begin{tabular}{|c|c|c|c|}
\hline $\begin{array}{l}\text { Oh et al, } \\
2005\end{array}$ & $\begin{array}{l}1^{\text {st }} \text { quantile }= \\
10.1 \% \\
5^{\text {th }} \text { quantile= } \\
17.6 \%\end{array}$ & $\begin{array}{l}\text { CHD } \\
\text { cases } \\
1,766\end{array}=$ & $\begin{array}{l}\text { RR (Total SFs) } \\
=0.97,95 \% \mathrm{CI} \\
(0.74-1.27)\end{array}$ \\
\hline
\end{tabular}

Age, BMI, alcohol intake, smoking, history of hypertension, aspirin use, energy intake, protein intake, cholesterol.

Intake, PA, vitamin E supplement use, multivitamin use, aspirin use, menopausal status and hormone use, history of hypertension, parental history of myocardial infarction.
-Total SFs intake was inversely associated with higher CHD (3\% reduction) when highest quartile compared to the lowest quartile.

\begin{tabular}{|c|c|c|c|}
\hline \multirow{4}{*}{$\begin{array}{l}\text { Tucker et } \\
\text { al, } 2005\end{array}$} & \multirow{4}{*}{$12.3 \%$} & \multirow{4}{*}{$\begin{array}{l}\text { CHD } \\
\text { deaths= } \\
71\end{array}$} & $\begin{array}{l}\text { HR (Total SFs) } \\
=1.07 ; 95 \% \text { CI } \\
(1.03-1.11) .\end{array}$ \\
\hline & & & $\begin{array}{l}\text { HR (Low SF } \\
\text { and Low FV) }= \\
0.41 ; \quad 95 \% \quad \text { CI } \\
(0.17-0.98) .\end{array}$ \\
\hline & & & $\begin{array}{l}\text { HR (Low SF } \\
\text { and High FV) }\end{array}$ \\
\hline & & & $\begin{array}{l}0.24 ; 95 \% \\
(0.11-0.52) .\end{array}$ \\
\hline
\end{tabular}

Age, BMI, physical activity score, smoking, dietary supplements, alcohol consumption, total energy intake.

$7 \%$ increase risk in CHD mortality by SF after adjusting the control variables $(\mathrm{p}<0.001)$.

-Those who consume $<12 \%$ of SF (low level) and low level of FV were $59 \%$ less likely to die from CHD $(p<0.05)$ compared to those consume $>12 \%$.

- Those who met the recommended level of FV\& SF level were $76 \%$ less likely to die from CHD.

-CHD mortality among those aged (47-59) in the highest SFs quartile was 5.17 times higher compared to those in the lowest quartile.

(age 47-59) Dakota was the reference centre)

\begin{tabular}{|c|c|c|c|}
\hline $\mathrm{Xu}$ et al, & $\begin{array}{l}1^{\text {st }} \text { quantile }= \\
7.5 \%\end{array}$ & CHD & $\begin{array}{l}=5.17,95 \% \text { CI } \\
(1.64-16.36)\end{array}$ \\
\hline 2006 & $\begin{array}{l}4^{\text {th }} \text { quantile }= \\
16.5 \%\end{array}$ & $\begin{array}{l}\text { deaths = } \\
138\end{array}$ & $\begin{array}{l}\text { RR (age 60-79) } \\
=0.80, \quad 95 \quad \mathrm{CI} \\
(0.41-1.54)\end{array}$ \\
\hline
\end{tabular}

variable of interest as a percentage of energy (quartiles), age, sex, study centre (South diabetes status, BMI, HDL, LDL, triacylglycerol (log-transformed), smoking (current vs ever and never), alcohol consumption (current vs ever and never), hypertension, percentage of energy from protein, and total energy intake.
-Among those aged (60-79) in the highest SFs intake quartile, CHD mortality is less by $20 \%$ compared to those in the lowest quartile. 


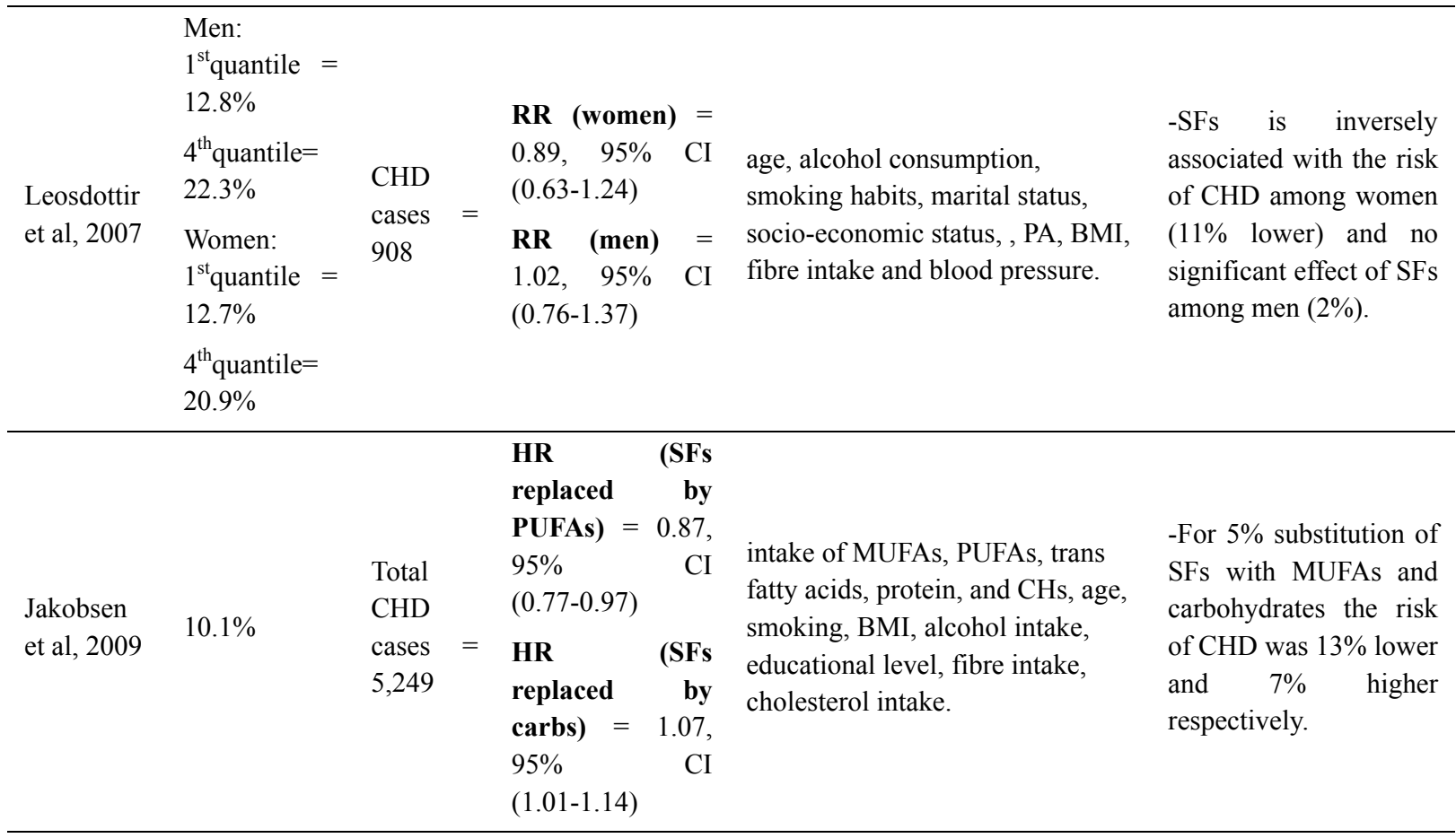

\begin{tabular}{lll}
\hline & Male: & \\
& $1^{\text {st }}$ quantile $=$ & \\
& $9.2 \%$ \\
& $5^{\text {th }}$ quantile= & \\
& $20.3 \%$ & CHD \\
Yamagishi & Female: $\quad$ deaths $=$ \\
et al, $2010 \quad$ & $1^{\text {st }}$ quantile $=420$ \\
& $9.4 \%$ & \\
& $5^{\text {th }}$ quantile= \\
& $19.8 \%$
\end{tabular}

HR (Total SFs)

$=0.93 ; 95 \% \mathrm{CI}$

(0.65-1.35)
Age, sex, smoking status, alcohol consumption, BMI, mental stress, walking, sports, educational level, and dietary intakes of total energy, cholesterol, $x-3$ and $x-6$ polyunsaturated fatty acids, history of hypertension and diabetes, vegetable and fruit,
-Those who consume SFs $(17.9-40.0)(\mathrm{g} / \mathrm{d})^{2}$ (highest quartile) were less likely to die from CHD by $7 \%$ compared to those consume $(2.5$ to $<11.0)(\mathrm{g} / \mathrm{d})^{2}$ (lowest quartile)

-SFs are protective factor from CHD mortality.

\begin{tabular}{|c|c|c|c|c|c|c|}
\hline $\begin{array}{l}\text { Oliveria } \\
\text { Otto et al, } \\
2012\end{array}$ & $\begin{array}{l}1^{\text {st }} \text { quantile }= \\
12.2 \% \\
5^{\text {th }} \text { quantile }= \\
25.3 \%\end{array}$ & $\begin{array}{l}\text { Total } \\
\text { CHD } \\
\text { cases } \\
231\end{array}$ & $=$ & 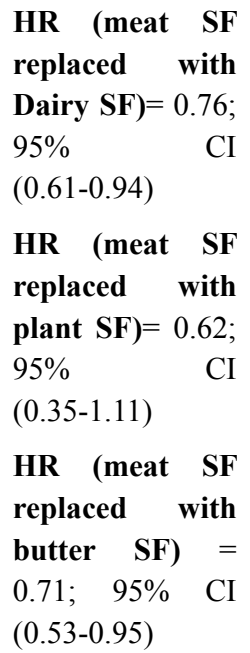 & $\begin{array}{l}\text { energy intake, age, sex, } \\
\text { race-ethnicity, study center, } \\
\text { education, alcohol intake, } \\
\text { physical activity, BMI, cigarette } \\
\text { smoking, dietary supplement use } \\
\text { and use of cholesterol lowering } \\
\text { medication. }\end{array}$ & $\begin{array}{l}\text {-The incidence of CHD } \\
\text { is reduced by } 24 \% \text { and } \\
38 \% \text { when SFs from } \\
\text { meat is replaced with } \\
\text { the same amount with } \\
\text { SFs from dairy and } \\
\text { plant respectively. }\end{array}$ \\
\hline $\begin{array}{l}\text { Virtanen et } \\
\text { al, } 2014\end{array}$ & $\begin{array}{l}1^{\text {st }} \text { quantile }= \\
13.4 \% \\
4^{\text {th }} \text { quantile }= \\
22.8 \%\end{array}$ & $\begin{array}{l}\text { CHD } \\
\text { cases } \\
382\end{array}$ & $=$ & $\begin{array}{l}\text { HR (Total SFs) } \\
=1.05 ; 95 \% \mathrm{CI} \\
(0.70-1.57)\end{array}$ & $\begin{array}{l}\text { age, examination year and energy } \\
\text { intake, BMI, diabetes mellitus, } \\
\text { hypertension, family history of } \\
\text { coronary heart disease, pack-years } \\
\text { of smoking, education, } \\
\text { leisure-time physical activity, }\end{array}$ & $\begin{array}{l}\text {-Total SFs was not } \\
\text { significantly associated } \\
\text { with risk of CHD. }\end{array}$ \\
\hline
\end{tabular}


intakes of alcohol and fibre, and

percentage of energy from

protein, and percentage of energy

from remaining fatty acids.

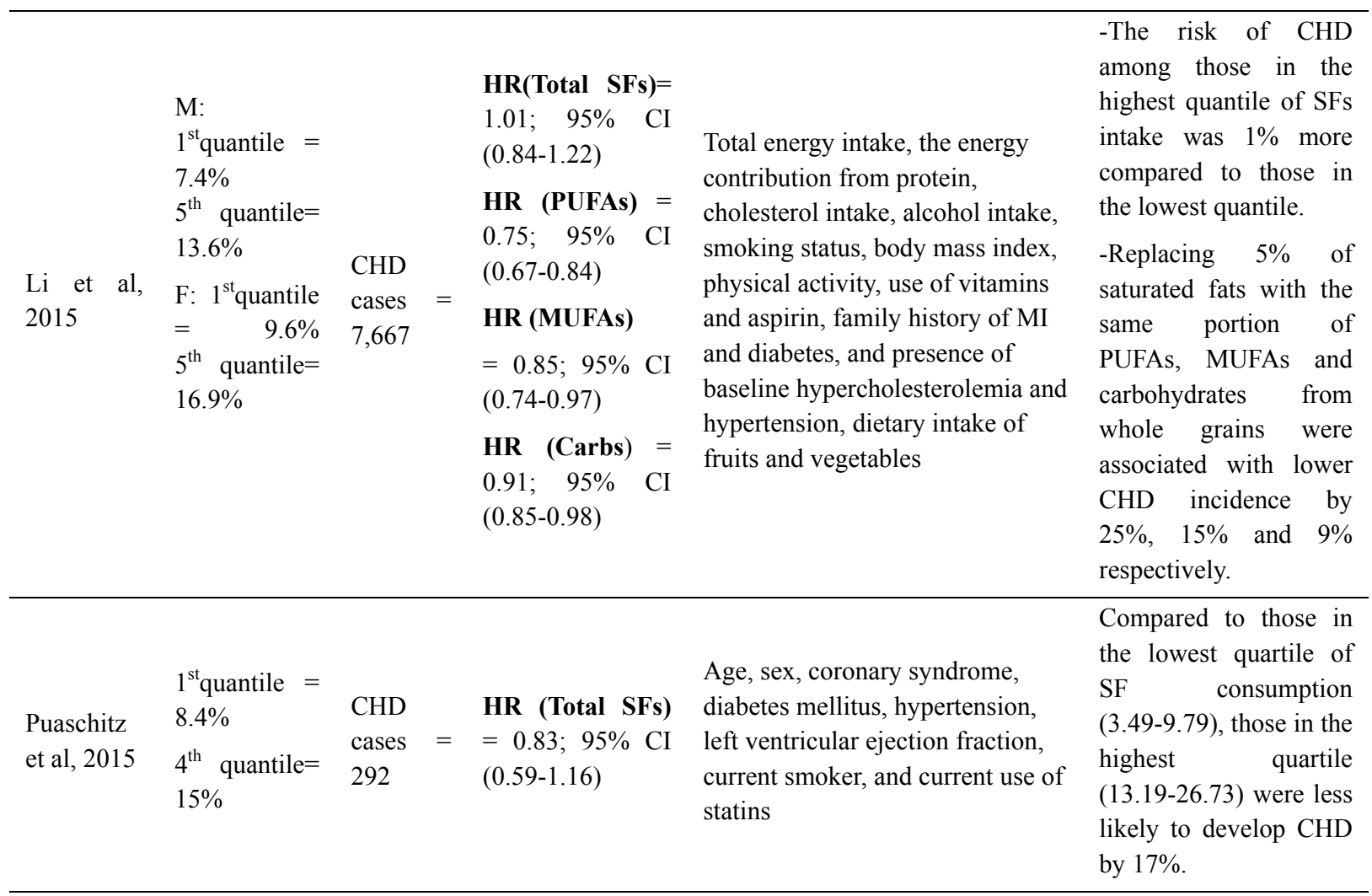

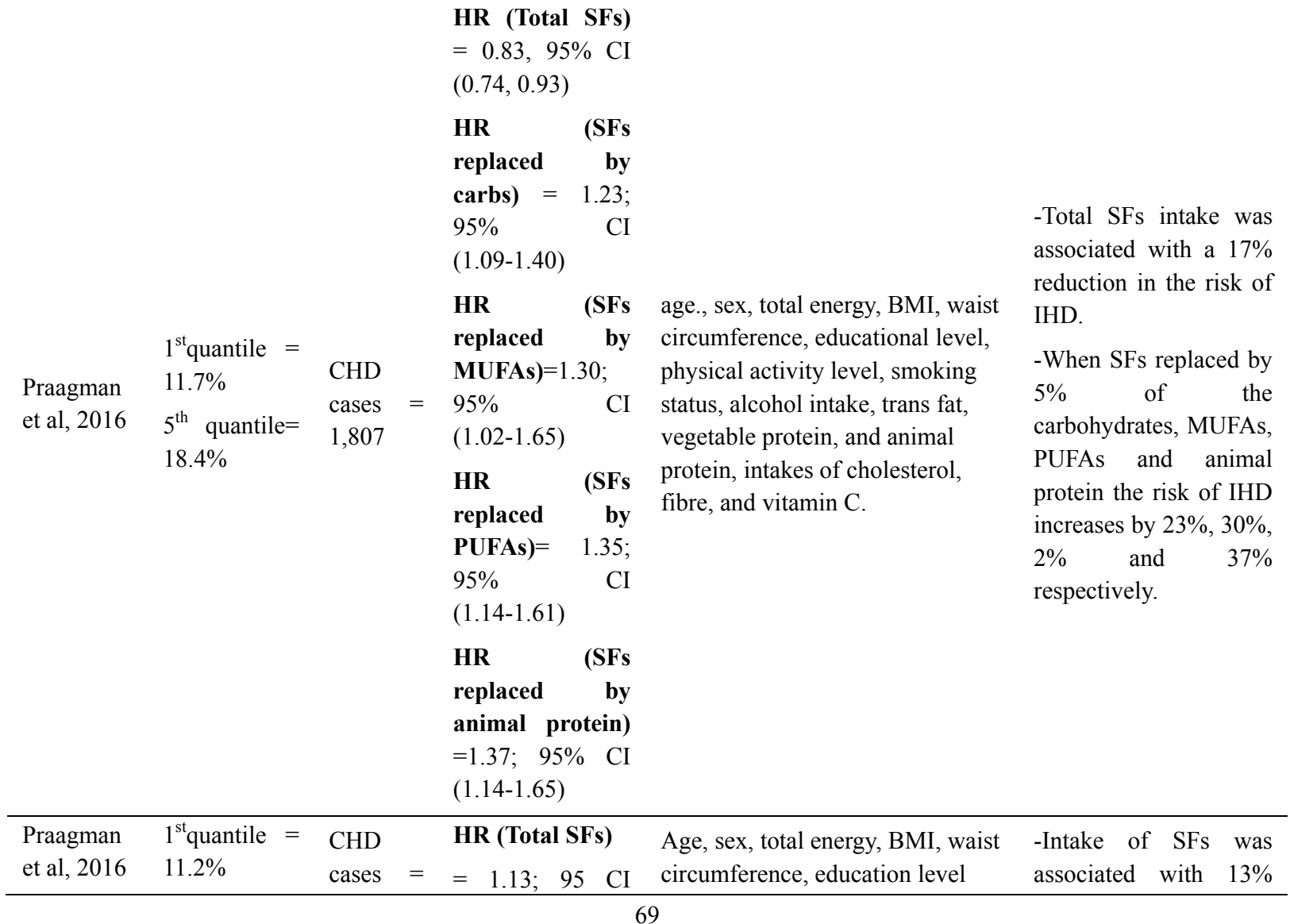




$\begin{array}{ll}5^{\text {th }} \text { quantile }=659 & (0.94-1.22) \\ 20.8 \% & \text { HR (Carbs for } \\ & \text { SFs) }=0.78 ; 95 \% \\ & \text { CI }(0.53-1.15) \\ & \text { HR } \quad \text { (animal } \\ & \text { protein for SFs) } \\ & 1.24 ; 95 \% \quad \text { CI } \\ & (1.01-1.51)\end{array}$

\begin{tabular}{|c|c|c|c|c|c|c|c|}
\hline $\begin{array}{l}\text { Zong et al, } \\
2016\end{array}$ & $\begin{array}{l}\text { NHS: } \\
1^{\text {st }} \text { quantile }= \\
8.2 \% ; \quad 5^{\text {th }} \\
\text { quantile } \\
=15 \% \\
\text { HPFS: } \\
1^{\text {st }} \text { quantile }= \\
6.9 \% ; \quad 5^{\text {th }} \\
\text { quantile } \\
=14.3 \%\end{array}$ & $\begin{array}{l}\text { CHD } \\
\text { cases } \\
7,035\end{array}$ & $=$ & $\begin{array}{l}\text { HR (all } \\
\text { combined) } \\
1.18 ; \quad 95 \% \\
(1.09-1.28)\end{array}$ & $\begin{array}{r}\text { SFs } \\
= \\
\text { CI }\end{array}$ & $\begin{array}{l}\text { Age, ethnicity, smoking status, } \\
\text { alcohol intake, family history of } \\
\text { myocardial infarction, } \\
\text { menopausal status } \\
\text { and postmenopausal hormone use, } \\
\text { physical activity, current aspirin } \\
\text { use, multivitamin use, baseline } \\
\text { hypertension, baseline } \\
\text { hypercholesterolemia, BMI, } \\
\text { and total energy intake }\end{array}$ & $\begin{array}{l}\text {-The risk of CHD } \\
\text { among the highest } \\
\text { quartile of SFs } \\
\text { consumption is } 18 \% \\
\text { higher compared to the } \\
\text { lowest quartile. } \\
\text {-Total SFs intake is } \\
\text { positively associated } \\
\text { with CHD. }\end{array}$ \\
\hline
\end{tabular}

Table 3. Age differences in the association between CHD (mortality \& incidence) and SFs in selected articles which report the association by age

\begin{tabular}{|c|c|c|c|c|c|c|c|}
\hline \multirow[b]{2}{*}{ Study } & \multicolumn{2}{|l|}{ Men } & \multicolumn{2}{|l|}{ Women } & \multicolumn{2}{|l|}{ Total } & \multirow{2}{*}{ Comments } \\
\hline & $<60$ years & $\geq 60$ years & $<60$ years & $\geq 60$ years & $<60$ years & $\geq 60$ years & \\
\hline $\begin{array}{l}\text { Jakobsen } \\
\text { et al, } \\
2004\end{array}$ & $\begin{array}{l}1.29 \\
(0.87-1.91)\end{array}$ & $\begin{array}{l}0.94 \\
(0.70-1.28)\end{array}$ & $\begin{array}{l}2.68 \\
(1.40-5.12)\end{array}$ & $\begin{array}{l}1.22 \\
(0.86-1.71)\end{array}$ & & & $\begin{array}{l}\text { SFs are positively } \\
\text { associated } \\
\text { CHD with } \\
\text { younger among } \\
\text { and men aged }<60 \\
\text { years, but not } \\
\text { among } \\
\text { women older } \\
\text { men }>60 \text { years. }\end{array}$ \\
\hline $\begin{array}{l}\mathrm{Xu} \text { et al, } \\
2006\end{array}$ & & & & & $\begin{array}{l}5.17 \\
(1.64-16.36)\end{array}$ & $\begin{array}{l}0.80 \\
(0.41-1.54)\end{array}$ & $\begin{array}{l}\text { SFs intake is a risk } \\
\text { factor for CHD } \\
\text { among those aged } \\
<60 \text { years and it is } \\
\text { a protective factor } \\
\text { among those aged } \\
\geq 60 \text { years. }\end{array}$ \\
\hline $\begin{array}{l}\text { Jakobsen } \\
\text { et al, } \\
2009\end{array}$ & $\begin{array}{l}\text { (MUFAs } \\
\text { for SFs) }= \\
1.13 \quad(0.74, \\
1.72) \\
\text { (PUFAs for } \\
\text { SFs) }=0.90 \\
(0.72,1.12)\end{array}$ & $\begin{array}{l}\text { (MUFAs } \\
\text { for SFs) }= \\
1.43 \quad(1.04, \\
1.96) \\
\text { (PUFAs for } \\
\text { SFs) }=0.81 \\
(0.65,1.01)\end{array}$ & $\begin{array}{l}\text { (MUFAs for } \\
\text { SFs) }=1.03 \\
(0.73-1.44) \\
\text { (PUFAs for } \\
\text { SFs) }=0.73 \\
(0.53,1.01)\end{array}$ & $\begin{array}{l}\text { (MUFAs for } \\
\text { SFs) }=1.27 \\
(0.74,2.17) \\
\text { (PUFAs for } \\
\text { SFs) }=1.22 \\
(0.84,1.77)\end{array}$ & & & $\begin{array}{l}\text {-Replacing SFs } \\
\text { with MUFAs } \\
\text { among men and } \\
\text { women } \\
\text { positively } \\
\text { associated with } \\
\text { CHD for all ages. } \\
\text {-Replacing SFs } \\
\text { with PUFAs is } \\
\text { inversely } \\
\text { associated with } \\
\text { CHD for men and }\end{array}$ \\
\hline
\end{tabular}




$(1.00,1.24) \quad(1.00,1.29) \quad(0.86,1.12) \quad(0.88,1.36)$

women except for women aged $\geq 60$ years.

-Replacing SFs with carbohydrate is positively associated with CHD among men and women except for women aged $<$ 60 years.

Tables 1 and 2 illustrate the general characteristics and the most important findings of the 14 studies included in this review arranged by the year published. Out of the 14 studies, 7 were from the USA, 2 from Netherlands and the remaining five studies were from Denmark, Sweden, Finland, Norway and Japan. The total number of participants in all studies was 810,389 ranges from (501 to 344,696) with age range from the youngest 20 years to the oldest 84 years at baseline. However, the lower age limit in most studies was 30 years and above, except for two studies (Puaschitz et al., 2014; Praagman et al., 2016). The percentage of males in studies which include both sexes ranges from $25 \%$ to about $50 \%$, except for one study the percentage of men was $81 \%$ (Puaschitz et al., 2014). The follow-up period ranges from 4.8 years to 30 years in which CHD deaths or incidents occurred. During the follow-up period, there were 629 CHD deaths and 26,322 cases occurred.

In addition, Table 1 lists the tools used in each study to measure the dietary intake outcomes. Dietary intake was assessed using food frequency questionnaire in the majority of the studies, except 5 studies which used a seven-day record or diary (Jakobsen, Overvad, Dyerberg, Schroll, \& Heitmann, 2004; Leosdottir, Nilsson, Nilsson, \& Berglund, 2007), dietary records (Tucker, Hallfrisch, Qiao, Muller, Andres, \& Fleg, 2005), a 24-h dietary recall $(\mathrm{Xu}, 2006)$ and 4-day food recording (Virtanen, Mursu, Tuomainen, \& Voutilainen, 2014). Deaths of CHD were obtained from death certificates and CHD incidents were attained from the medical records in hospitals.

The relation between SFs intake and the CHD mortality was reported in three studies in this review (Tucker, Hallfrisch, Qiao, Muller, Andres, \& Fleg, 2005; Xu et al., 2006; Yamagishi et al., 2010). However, results of the studies were controversial with regard to CHD mortality. For instance, total SFs intake found to increase the risk of CHD mortality by 7\% with 95\% CI (3\%-11\%) (Tucker et al., 2005). Conflict results were found by another study where total SFs intake was found to decrease the risk of dying from CHD by the same amount, which is $7 \%$ (Yamagishi et al., 2010). However, this association is not significant because the 95\% CI includes one (0.65-1.35). On the other hand, one study reported the association between CHD mortality and SFs by age classified as $<60$ years and above 60 years (Xu et al., 2006). Total SFs was found to be significant positive risk factor for $\mathrm{CHD}$ mortality for those younger than 60 years $(\mathrm{HR}=5.17$; 95\% CI 1.64-16.36), but this association was not observed for those aged 60 years and above (Xu et al., 2006). Thus, findings on the association between CHD mortality and SFs were inconsistent.

The association between the incidence of CHD and the intake of SFs were reported in different ways among studies. For instance, seven studies reported the association between the total SFs intake and the incidence of CHD. Three out of the seven studies reported inverse association between CHD and SFs with hazard ratios HR= 0.97 (0.71-1.27), 0.83 (0.59-1.16), 0.83 (0.74-0.93) respectively (Oh et al., 2005; Puaschitz et al., 2014; Praagman et al., 2016). However, this association was not significant because all HRs are close to one and their 95\% CIs cross one except for one study (Praagman et al., 2016). On the other hand, a positive relation was found in two studies where the risk of CHD was higher by 13\% and 18\% (Praagman et al., 2016; Zong et al., 2016) and no association was found in two studies HR=1.05 (0.7-1.57) and 1.01 (0.84-1.22) (Virtanen, Mursu, Tuomainen, \& Voutilainen, 2014; Li et al., 2015).

Sex differences in the association between SFs and CHD were reported in two studies (Jakobsen et al., 2004; Leosdottir, Nilsson, Nilsson, \& Berglund, 2007). No association was found among men in both studies HR was $1.03(0.78-1.37)$ and $1.02(0.76-1.37)$ respectively (Jakobsen et al., 2004; Leosdottir et al., 2007). In contrast, SFs were positively associated with CHD among women in one study (HR=1.36; 0.98-1.88) (15), but conflict result was found by the other study where SFs was inversely associated to SFs among women $(\mathrm{HR}=0.89$; 0.63-1.24) (Leosdottir et al., 2007). 
Age differences in the association between CHD and SFs were summarised in Table (3) where 3 studies only reported age differences (Jakobsen et al., 2004; Xu et al., 2006). One study reported CHD mortality already mentioned above (Xu et al., 2006). However, when analysis includes both age and sex, it was found that SFs is a risk factor for both men and women except among men $\geq 60$ years (HR=0.94; 0.70-1.28) (Jakobsen et al., 2004).

Replacing SFs with the same amount of other nutrients such as MUFAs, PUFAs and Carbs was reported by sex and age in one study (Leosdottir et al., 2007). The substitution of SFs by MUFAs was positively associated with CHD for all ages and both sexes. In contrast, when SFs were replaced by PUFAs, the CHD risk was lower for all categories except for women $\geq 60$ years $H R=1.22(0.84,1.77)$ (Leosdottir et al., 2007). Furthermore, substituting SFs by the same amount of Carbs was positively associated with the risk of CHD except for younger women $<60$ years $\mathrm{HR}=0.98(0.86,1.12)$ (Leosdottir et al., 2007).

\section{Discussion}

This systematic review includes 14 observational cohort studies from 7 countries in which the association between SFs intake and CHD was reported. Yet, contradictory results were found between studies in this review. CHD incidence or mortality were included as endpoints in these studies. On the other hand, dietary intake was measured using self-reported tools. Inconsistency among findings need to be addressed well to help in implementing evidence-based dietary guidelines.

Dietary recommendations restrict SFs intake as they are believed to cause CHD. However, four studies only in this review found a positive association between SFs and the risk of CHD(Jakobsen et al., 2004; Xu et al., 2006; Praagman et al., 2016; Zong et al., 2016). The highest HR=5.17 (1.64-16.36) which is related to CHD deaths among particular age group ( $<60$ years) only, but not among those aged $\geq 60$ years in this study (Xu et al., 2006). However, the small number of deaths (CHD deaths $=138)$ results in a wide confidence interval which makes the uncertainty higher in this study (Xu et al., 2006). On the other hand, modest and not significant increase or reduction in the risk of CHD and SFs was reported by half of the studies in this review where HRs range from 0.93 to 1.07 (Oh et al., 2005; Tucker et al., 2005; Leosdottir et al., 2007; Leosdottir et al., 2007; Leosdottir et al., 2007; Yamagishi et al., 2010; Virtanen et al., 2014; Li et al., 2015). Inverse association was reported by three studies out of the 14 studies included in this review (de Oliveira Otto et al., 2012; Puaschitz et al., 2014; Praagman et al., 2016). Thus, conflicting results were reported by the prospective cohort studies included in this review.

Replacing energy from SFs by the same amount of other nutrients or sources of SFs needs comprehensive investigation. For instance, one study reported that if meat SFs were replaced by the same amount of SFs from diary, plant and butter, the risk of CHD would be reduced by $24 \%, 38 \%$ and $29 \%$ respectively (de Oliveira Otto et al., 2012). Therefore, the source of SFs is important according to this study. On the other hand, when SFs where substituted by the same amount of MUFAs, PUFAs and Carbs is summarised in Table 4. Results from Table 4 show contradictory findings where MUFAs is positively associated to CHD when replacing SFs in two studies (Leosdottir et al., 2007; Praagman et al., 2016) whereas, it is a protective factor in another study (Li et al., 2015). In contrast, PUFAs were inversely associated in two studies (Leosdottir et al., 2007; Li et al., 2015) and inversely associated to CHD in one study (Praagman et al., 2016).

Table 4. The effect of replacing SFs by the same amount of different nutrients

\begin{tabular}{llll}
\hline & Li et al, 2015 (24) & Praagman et al, 2016 (26) & Jakobsen et al, 2009 (20) \\
\hline MUFAs & $0.85(0.74-0.97)$ & $1.30(1.02-1.65)$ & $1.19(1-1.42)$ \\
PUFAs & $0.75(0.67-0.84)$ & $1.35(1.14-1.61)$ & $0.87(0.77-0.97)$ \\
Carb & $0.91(0.85-0.98)$ & $1.23(1.09-1.40)$ & $1.07(1.01-1.14)$ \\
\hline
\end{tabular}

The variations of the results between studies can be explained in different ways. One of the most reasons could be the self-reported measurements of dietary intakes such as food frequency questionnaire and the 4 or 7-day food recording. All studies in this review reported dietary intakes based on self-reported measurements which are prone to bias. Hence, the weak association between SFs and CHD can be interpreted as a result of the unreliability of the self-reported dietary information in the observational studies (Kromhout, Geleijnse, Menotti, \& Jacobs, 2011). In addition, this aspect can be a potential source of random error (Tucker, Hallfrisch, Qiao, Muller, Andres, \& Fleg, 2005). However, random error can be reduced by using multiple 24-hours recalls (Xu et al., 2006). Furthermore, measuring dietary intakes at baseline only is insufficient and can't measure the changes 
in dietary intakes in long period cohort studies.

Using food frequency questionnaire was common among the majority of the studies in this review. However, dietary misclassification or outcome misclassification can attenuate the association into the null (Yamagishi et al., 2010). Although food frequency questionnaires are useful in large-scale prospective epidemiological studies, they are susceptible to measurement error (Date et al., 2005). A frequency questionnaire may be lengthy because it contains from 80 to 120 food items and may take up to one hour to be completed (National Cencer institute. Food Frequency Questionnaire at a Glance, 2017). Moreover, the exclusion criteria in those studies may be prone to information bias where large numbers excluded because their food frequency questionnaire was not completed. Thus, the answers of those who excluded may be different from those who included in the studies (Puaschitz et al., 2014).

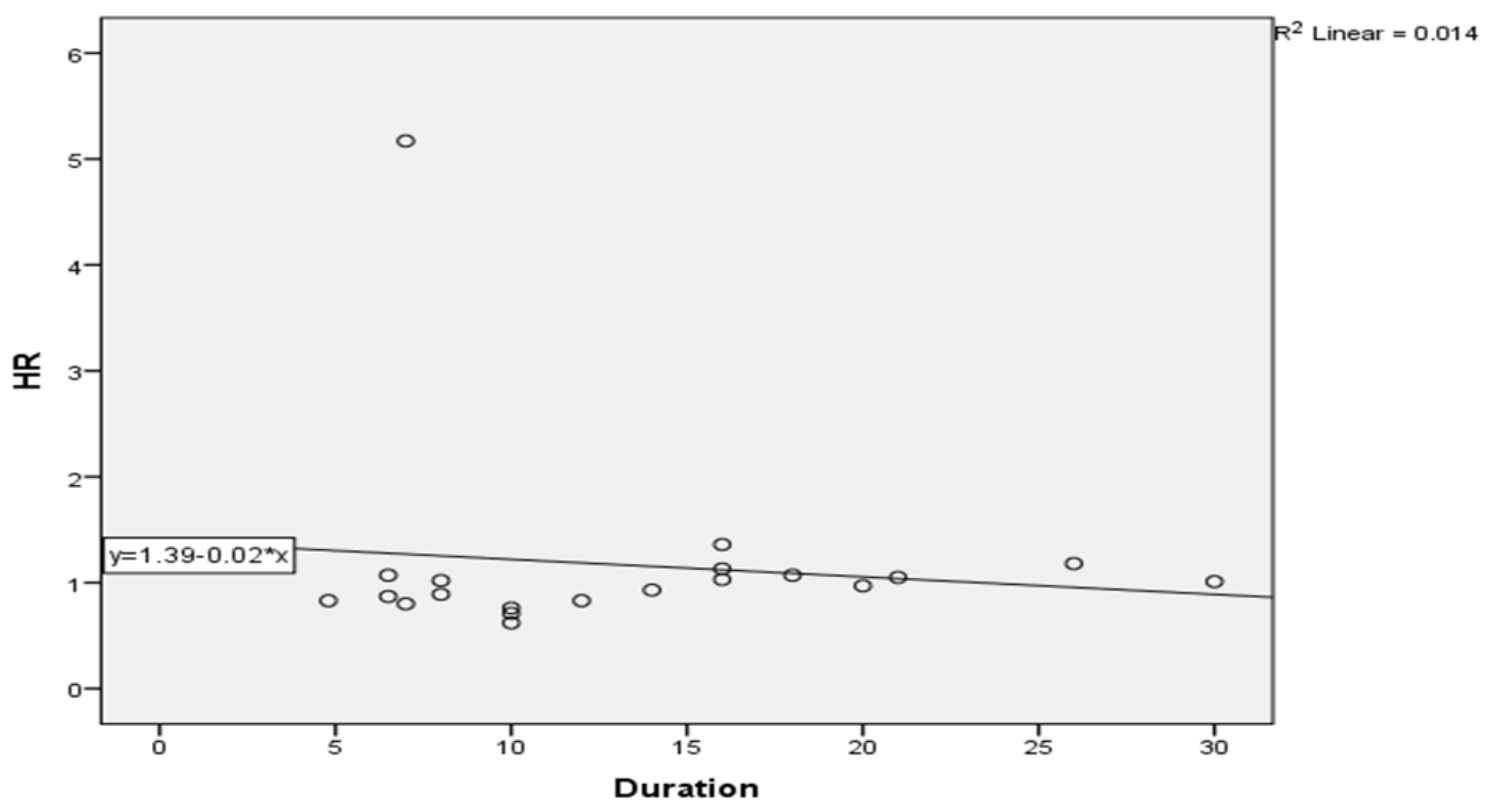

Figure 2. Scatterplot of the relation between duration of follow-up and hazard ratio (HR)

Lifestyles behaviours and other potential confounders were controlled in all studies. However, in prospective cohort studies residual confounders cannot be excluded (Puaschitz et al., 2014). This may also contribute to the variations of results among studies. On the other hand, the duration of follow-up and hazard ratio was not found to be correlated in studies included in this review where $1.4 \%$ only of the variation of the hazard ratios was explained by duration $\left(\mathrm{R}^{2}=0.014\right)$ (Figure 2 ).

There is a lack of studies on the age and sex differences in the association of SFs intake and the CHD studies. This subgroup analysis clearly identifies the effect of SFs on the younger people ( $<60$ years) and older people $(\geq$ 60 years). However, this review found inconsistent results in the relation of CHD and SFs among men and women as well as among younger and older people.

Given the nature of the observational epidemiological studies, causality cannot be approved between CHD and SFs (Xu et al., 2006). Those people with high risk of CHD may use to consume more fats for many reasons compared to healthy people. Thus, results in this type of studies should be interpreted with caution. Furthermore, the 14 studies included in this review came from developed countries and half of them were from the USA. Fat intake and food sources are different from those in developing countries or the Arab world. Thus, generalisability of the results is limited and more research is needed in developing and Arab countries. Evidence show that the geographical location and the number of events can affect or change the results (Chowdhury et al., 2014).

In conclusion, this systematic review of the 14 cohort studies found conflicting results regarding the relation of SFS intake and the risk of CHD. Four studies only show positive association and the other ten show no association or inverse association between SFs and CHD. Therefore, we can argue that there is no association between SFs intake and higher risk of CHD because the majority of the prospective cohort studies support this finding. However, research should be continued in this area. 


\section{Strengths and limitations}

The main strength of this review is that it includes high-quality peer-reviewed prospective cohort studies with large sample sizes and long follow-up periods. However, the number of studies included in this review is relatively small compared to the published studies. Different dietary measurement tools were used in the 14 studies in which all were based on subjective data.

\section{Future research and gap of knowledge}

1) There is a lack of studies addressing age and gender differences on the association of CHD and SFs intake.

2) No studies were found from developing or Arab countries.

3) Dietary intake should be measured at baseline and repeated during the follow-up period.

4) All studies in this review rely on subjective data. Therefore, there is a need to use objective data which give better estimates of fats.

\section{Competing Interests Statement}

The authors declare that there are no competing or potential conflicts of interest.

\section{References}

Baum, S. J., Kris-Etherton, P. M., Willett, W. C., Lichtenstein, A. H., Rudel, L. L., Maki, K. C., ... \& Block, R. C. (2012). Fatty acids in cardiovascular health and disease: a comprehensive update. Journal of clinical lipidology, 6(3), 216-234. https://doi.org/10.1016/j.jacl.2012.04.077

Chowdhury, R., Warnakula, S., Kunutsor, S., Crowe, F., Ward, H. A., Johnson, L., ... \& Khaw, K. T. (2014). Association of dietary, circulating, and supplement fatty acids with coronary risk: a systematic review and meta-analysis. Annals of internal medicine, 160(6), 398-406. https://doi.org/10.7326/M13-1788

Christensen, K., Doblhammer, G., Rau, R., \& Vaupel, J. W. (2009). Ageing populations: the challenges ahead. The lancet, 374(9696), 1196-208. https://doi.org/10.1016/S0140-6736(09)61460-4

Date, C., Fukui, M., Yamamoto, A., Wakai, K., Ozeki, A., Motohashi, Y., ... \& Kurisu, Y. (2005). Reproducibility and validity of a self-administered food frequency questionnaire used in the JACC study. Journal of Epidemiology, 15(Supplement_I), S9-S23.

de Oliveira Otto, M. C., Mozaffarian, D., Kromhout, D., Bertoni, A. G., Sibley, C. T., Jacobs Jr, D. R., \& Nettleton, J. A. (2012). Dietary intake of saturated fat by food source and incident cardiovascular disease: the Multi-Ethnic Study of Atherosclerosis-. The American journal of clinical nutrition, 96(2), 397-404. https://doi.org/10.3945/ajen.112.037770

de Oliveira Otto, M. C., Mozaffarian, D., Kromhout, D., Bertoni, A. G., Sibley, C. T., Jacobs Jr, D. R., \& Nettleton, J. A. (2012). Dietary intake of saturated fat by food source and incident cardiovascular disease: the Multi-Ethnic Study of Atherosclerosis-. The American journal of clinical nutrition, 96(2), 397-404. https://doi.org/10.3945/ajen.112.037770

De Souza, R. J., Mente, A., Maroleanu, A., Cozma, A. I., Ha, V., Kishibe, T., ... \& Anand, S. S. (2015). Intake of saturated and trans unsaturated fatty acids and risk of all cause mortality, cardiovascular disease, and type 2 diabetes: systematic review and meta-analysis of observational studies. Bmj, 351, h3978. https://doi.org/10.1136/bmj.h3978

Hoenselaar, R. (2012). Saturated fat and cardiovascular disease: the discrepancy between the scientific literature and dietary advice. Nutrition, 28(2), 118-23. https://doi.org/10.1016/j.nut.2011.08.017

Jakobsen, M. U., Overvad, K., Dyerberg, J., Schroll, M., \& Heitmann, B. L. (2004). Dietary fat and risk of coronary heart disease: possible effect modification by gender and age. American journal of epidemiology, 160(2), 141-149. https://doi.org/10.1093/aje/kwh193

Kromhout, D., Geleijnse, J. M., Menotti, A., \& Jacobs, D. R. (2011). The confusion about dietary fatty acids recommendations for CHD prevention. British journal of nutrition, 106(5), 627-632. https://doi.org/10.1017/S0007114511002236

Leosdottir, M., Nilsson, P. M., Nilsson, J. Å., \& Berglund, G. (2007). Cardiovascular event risk in relation to dietary fat intake in middle-aged individuals: data from The Malmö Diet and Cancer Study. European Journal of Cardiovascular Prevention \& Rehabilitation, 14(5), 701-706. 
https://doi.org/10.1097/HJR.0b013e3282a56c45

Leosdottir, M., Nilsson, P. M., Nilsson, J. Å., \& Berglund, G. (2007). Cardiovascular event risk in relation to dietary fat intake in middle-aged individuals: data from The Malmö Diet and Cancer Study. European Journal of Cardiovascular Prevention \& Rehabilitation, 14(5), 701-706. https://doi.org/10.3945/ajen.2008.27124

Li, Y., Hruby, A., Bernstein, A. M., Ley, S. H., Wang, D. D., Chiuve, S. E., ... \& Hu, F. B. (2015). Saturated fats compared with unsaturated fats and sources of carbohydrates in relation to risk of coronary heart disease: a prospective cohort study. Journal of the American College of Cardiology, 66(14), 1538-1548. https://doi.org/10.1016/j.jacc.2015.07.055

Lins, N. E., Jones, C. M., \& Nilson, J. R. (2010). New frontiers for the sustainable prevention and control of non-communicable diseases (NCDs): a view from sub-Saharan Africa. Global health promotion, 17(2_suppl), 27-30.

National Cencer institute. Food Frequency Questionnaire at a Glance. (2017). Retrieved from https://dietassessmentprimer.cancer.gov/profiles/questionnaire/

Oh, K., Hu, F. B., Manson, J. E., Stampfer, M. J., \& Willett, W. C. (2005). Dietary fat intake and risk of coronary heart disease in women: 20 years of follow-up of the nurses' health study. American journal of epidemiology, 161(7), 672-679. https://doi.org/10.1093/aje/kwi085

Parodi, P. W. (2015). Dietary guidelines for saturated fatty acids are not supported by the evidence. International Dairy Journal, 52, 115-23. https://doi.org/10.1016/j.idairyj.2015.08.007

Perk J, De Backer G, Gohlke H, Graham I, Reiner Z, Verschuren W, et al. (2013). European Guidelines on Cardiovascular Disease Prevention in Clinical Practice (version 2012). The Fifth Joint Task Force of the European Society of Cardiology and other societies on cardiovascular disease prevention in clinical practice (constituted by representatives of nine societies and by invited experts). Giornale italiano di cardiologia 14(5), 328 .

Praagman, J., Beulens, J. W., Alssema, M., Zock, P. L., Wanders, A. J., Sluijs, I., \& Van Der Schouw, Y. T. (2016). The association between dietary saturated fatty acids and ischemic heart disease depends on the type and source of fatty acid in the European Prospective Investigation into Cancer and Nutrition-Netherlands cohort, 2. The American journal of clinical nutrition, 103(2), 356-365. https://doi.org/10.3945/ajcn.115.122671

Praagman, J., de Jonge, E. A., Kiefte-de Jong, J. C., Beulens, J. W., Sluijs, I., Schoufour, J. D., ... \& Franco, O. H. (2016). Dietary saturated fatty acids and coronary heart disease risk in a Dutch middle-aged and elderly population. Arteriosclerosis, thrombosis, and vascular biology, ATVBAHA-116.

Puaschitz, N. G., Strand, E., Norekvål, T. M., Dierkes, J., Dahl, L., Svingen, G. F. T., ... \& Drevon, C. A. (2014). Dietary Intake of Saturated Fat Is Not Associated with Risk of Coronary Events or Mortality in Patients with Established Coronary Artery Disease-3. The Journal of nutrition, 145(2), 299-305. https://doi.org/10.3945/jn.114.203505

Siri-Tarino, P. W., Sun, Q., Hu, F. B., \& Krauss, R. M. (2010). Meta-analysis of prospective cohort studies evaluating the association of saturated fat with cardiovascular disease-. The American journal of clinical nutrition, 91(3), 535-546.

Tucker, K. L., Hallfrisch, J., Qiao, N., Muller, D., Andres, R., \& Fleg, J. L. (2005). The combination of high fruit and vegetable and low saturated fat intakes is more protective against mortality in aging men than is either alone: the Baltimore Longitudinal Study of Aging. The Journal of nutrition, 135(3), 556-561.https://doi.org/10.1093/jn/135.3.556

Virtanen, J. K., Mursu, J., Tuomainen, T. P., \& Voutilainen, S. (2014). Dietary fatty acids and risk of coronary heart disease in men: the Kuopio Ischemic Heart Disease Risk Factor Study. Arteriosclerosis, thrombosis, and vascular biology, ATVBAHA-114. https://doi.org/10.1161/ATVBAHA.114.304082

WebMD. (2005). Coronary Artery Disease. Retrieved from http://www.webmd.com/heart-disease/guide/heart-disease-coronary-artery-disease\#1.

Wikipedia tfe. (2017). Coronary artery disease 2017 Retrieved from https://en.wikipedia.org/wiki/Coronary_artery_disease

World Health Organisation [WHO]. (2017). Cardiovascular diseases (CVDs) [Fact sheet]. Retrieved from http://www.who.int/mediacentre/factsheets/fs317/en/ 
Xu, J., Eilat-Adar, S., Loria, C., Goldbourt, U., Howard, B. V., Fabsitz, R. R., ... \& Lee, E. T. (2006). Dietary fat intake and risk of coronary heart disease: the Strong Heart Study-. The American journal of clinical nutrition, 84(4), 894-902. https://doi.org/10.1093/ajcn/84.4.894

Yamagishi, K., Iso, H., Yatsuya, H., Tanabe, N., Date, C., Kikuchi, S., et al. (2010). Dietary intake of saturated fatty acids and mortality from cardiovascular disease in Japanese: the Japan Collaborative Cohort Study for Evaluation of Cancer Risk (JACC) Study. The American journal of clinical nutrition, 92(4), 759-65. https://doi.org/10.3945/ajen.2009.29146

Zimmet, P. Z., \& Alberti, K. (2006). Introduction: Globalization and the non - communicable disease epidemic. Obesity. 14(1), 1-3. https://doi.org/10.1038/oby.2006.1

Zong, G., Li, Y., Wanders, A. J., Alssema, M., Zock, P. L., Willett, W. C., ... \& Sun, Q. (2016). Intake of individual saturated fatty acids and risk of coronary heart disease in US men and women: two prospective longitudinal cohort studies. Bmj, 355, i5796.

\section{Copyrights}

Copyright for this article is retained by the author(s), with first publication rights granted to the journal.

This is an open-access article distributed under the terms and conditions of the Creative Commons Attribution license (http://creativecommons.org/licenses/by/4.0/). 